\title{
ANALYSIS OF SERVICE QUALITY, PERCEIVED VALUE AND CUSTOMER SATISFACTION TOWARDS CUSTOMER LOYALTY IN INSURANCE INDUSTRY - CASE STUDY OF PT. SYNERGY ADHI MANUNGGAL
}

Benedictus Widy Andhika, Nila Khrisnawati Hidayat, SE, MM.

Swiss German University, Tangerang, Indonesia
Dr.rer.nat. Linus Pasasa.

Swiss German University, Tangerang, Indonesia

The purpose of this research is to study and analyse the impact of service quality, perceived value, and customer satisfaction towards customer loyalty in insurance industry - case study of PT.Synergy Adhi Manunggal. The primary data was obtained by using the questionnaires to 100 customers of PT.Synergy Adhi Manunggal. The data is analysed using Structural Equation Modelling (SEM analysis to test the hypotheses). Finding of this research shows that service quality, perceived value, and customer satisfaction have a significant positive influence towards customer loyalty. In conclusion PT.Synergy Adhi Manunggal must be able to understand the effect of service quality, perceived value, and customer satisfaction towards customer loyal. It will be a great challenge for the PT.Synergy Adhi Manunggal in preparing their strategic plan in maintaining customer loyalty.

Service Quality, Perceived Value, Customer Satisfaction, Loyalty, Insurance. 


\section{INTRODUCTION}

I nsurance has been a growing secto $r$ in Indonesia for the last couple years. The insurance sector of Indonesia holds up to $10 \%$ of financial sector asset (IMF 2013). In total, we could highlight that insurance performance in Indonesia had experienced a downturn growth. The gross premium in 2013 was the lowest point by $9.8 \%$ since 2009 . It was suspected due to downturn in economic performance within the period. Up to 2011, the most preferred choice was life insurance subsequently decreased afterwards. Since 2012, the administering social insurance and social security programs had experienced sharp increase due to higher demand for this insurance option. The same performance also occurred in nonlife insurance as many people considered it as long-term investment for the future. Figure1.1 below exhibits the growth of gross premium of insurance in Indonesia over the $2009-2013$ periods.

Figure 1.1: The Growth of Insurance Gross Premium $2009-2013(\%)$

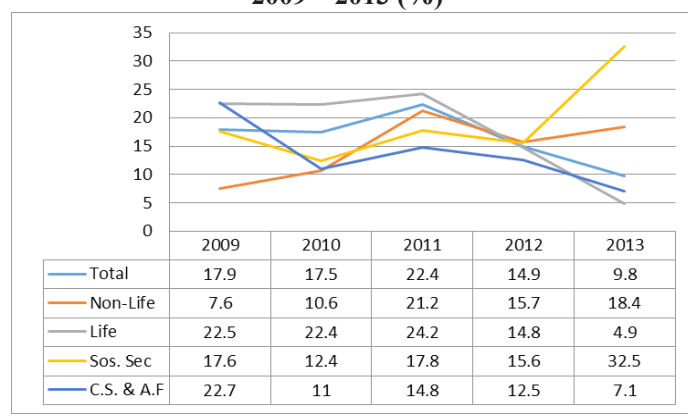

Source: OtoritasJasaKeuangan (2013)

Established in 1995, Prudential Indonesia is one of the 49 life insurance companies operating in Indonesia. It was a joint venture between two huge organizations that established PT Prudential Bank Bali Life Assurance. Unit linked insurance program is a blend of risk cover and investment. The premiums customers paid are utilized for insurance protection and the other portion of premium is for investment in multiple equity and debt scheme. PT Prudential Life Assurance has become a market leader of this product classification in Indonesia. The market shares of top 10 players is shown in Figure 1.2. The leading two players are Prudential and AXA Mandiri; however, while Prudential increased its market share from $23 \%$ to $24 \%$ in 2014 , AXA Mandiri's market share reduced from $12 \%$ to $9 \%$ during the same period.

As of 30 June 2014, Prudential Indonesia has its head office in Jakarta and branches in Surabaya, Medan, Denpasar, Batam and Semarang. Based on the report of Prudential I (2013), Prudential has more than 2.3 million clients across Indonesia and more than 200,000 sales executives in 371 agencies. PT. Synergy Adhi Manunggal is one of 371 agencies in Indonesia. PT. Synergy Adhi Manunggal was established in 27 July 2007. It is located at Central Jakarta and has over 2100 agents, 95 managers, 25 employees. The office manager of PT. Synergy Adhi Manunggal stated that the company has difficulties in improving their sales of repeat purchase, even though PT. Synergy Adhi Manunggal already increased the capacity for their sales force and aftersales service. (Setiawan, 2015).

Figure 1.2: The target repeat purchase in PT. Synergy Adhi Manunggal

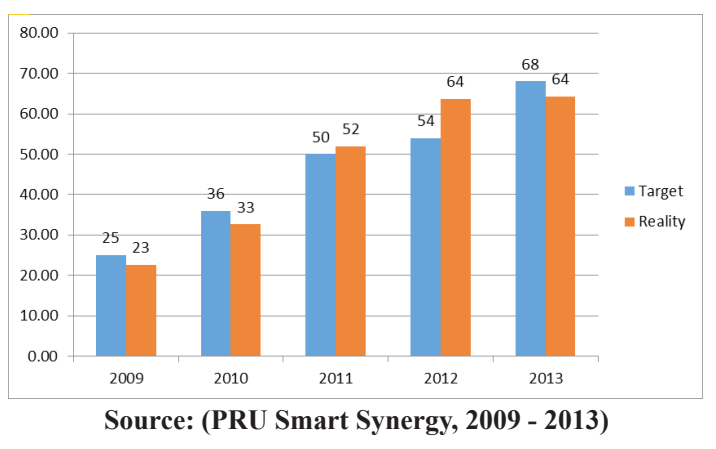


Figure 1.2 shows that target is not achieved. In 2009 PT. Synergy Adhi Manunggal targeted that they could achieve IDR 25 billion, but in fact only achieved IDR22.5 billion; same thing goes to 2010 and 2013 in which they targeted the annual target by respectively IDR 36 billion and IDR 68 billion but they only achieved IDR 32.7 billion and IDR 64.3 billion respectively; it is suspected that the target were not achieved due to lower customer satisfaction (Setiawan E., 2015). Based on interviews with the office managers of PT. Synergy Adhi Manunggal, the new agents provide poor quality customer service since they made unrealistic and oftentimes untrue promises to get customers. When customers want to claim or had a problem with their life insurance policy, the agent did not stand by to serve the customer and at this time the customer knows that the agents do not perform well and decided not to buy an insurance policy anymore. Furthermore, in today's competitive insurance business customers expect fast and efficient service.

Customer loyalty is the degree to which customers create a repeat purchase behavior from a product or service (Kheng, Mahamad, Ramayah, \& Rahim, 2010). With customer loyalty, it trigger customer to buy more product or doing repeat purchase behavior from the company. Customer loyalty itself gained by creating good service quality, perceives value and satisfied customer. Advantage of having customer loyalty is it can increase profit for the company. For example, this study discuss about insurance company. When customer happy with the service of the agent, it means the customer trust and buying more product or service in this insurance company.

Repeat purchase is an essential factor in the insurance business industry. One factor that can persuade customers to make a repeat purchase is the agent having integrity, professionalism and consistency in delivering the service to customers (Singh, Sirohi, and Chaudhary, 2014). Any clients who desire to arrange business with the company can be classified as repeat purchase, and it can be said that it is five to ten times less expensive to keep a client than to get a new customers (Vezifhedust and Farokhian, 2011). There are several variables that influence clients to make a repeat purchase. To differentiate and compete with competitors, companies should deliver high quality of service, and knowledgeable, and sociable employees in order to satisfy the clients. Satisfied clients are a one key to a successful business because client's satisfaction may lead to repeat purchase (Angelova \& Zekiri, 2011) and (Syed H, 2010). Furthermore, a customer satisfaction plays a large role enhancing the business. Research has shown that if clients are satisfied with a product or service, they tend to recommend or share an experience with around to five or six peoples (Nelson, 2012). This study research focuses on service quality and customer satisfaction that can affect customer loyalty of PT. Synergy Adhi Manunggal through customer satisfaction

\section{THEORY AND LITERA- TURE}

\section{II.I. Service Quality}

Service Quality is the primary determinant of both customer satisfaction and customer loyalty, especially in firms in which service is the core product. There are many researchers who have scientifically defined the concept of service quality itself. Zeithaml and Bitner (2003) in the paper of the Impact of Service Quality, 
Customer Satisfaction and Loyalty Programs on Customer's Loyalty, An Evidence from Telecommunication Sector by Sabir, Irfan, Sarwar, and Akhtar (2013) stated that "service quality is one of the major determinants of customer satisfaction". Parasuraman (1988) in the paper of the Impact of Service Quality on Customer Satisfaction of Mobil Users by Yadaf and Dabhade (2013) defined that service quality as "the degree and direction of discrepancy between the customer's perceptions and expectations, or the extent to which the service meets or exceeds customer expectations".

Yadaf and Dabdahde (2013) argued that "service quality is actually a gap between customer's perception of firm performance and their prior expectation". In addition, the theory is confirmed by Vazquel et al (2001) in the journal of Service Quality and Its Effect on Customer Satisfaction in Retailing (Naik, Gantasala, and Prabhakar, 2010) that "the service will be considered excellent if perceptions exceed expectations; it will be considered as good or adequate if perceptions are equal to expectations; and it will be considered bad of poor if expectations do not meet the customer's expectations". Tam (2004) and Dharmalingam (2011) in the paper of Impact of Service Quality on Customer Satisfaction,A Study on Customers of Commercial Bankof Ceylon PLC Trincomalee District by Navaratnaseelan and Elangkumaran (2014) stated that "customer with higher perceptions of the value of the service results in turn with higher satisfaction and all service quality dimensions became the primary determinant of customer satisfaction".

This study will use a service quality model modified by (Mehta \& Lobo, 2002) to analyze the correlation between service quality and customer satisfaction.
The model recommends 6 dimensions of service quality as shown in the following Table 2.1.

Table 2.1 Dimensions of Service quality

\begin{tabular}{|c|c|}
\hline Dimensions & Definitions \\
\hline Tangibles & $\begin{array}{l}\text { It refers to strategic location of building or } \\
\text { office, adequate number of office to service } \\
\text { customer better and faster, great environment } \\
\text { and atmosphere of the office. This consists of } \\
\text { providing physical facilities, equipment, } \\
\text { personnel and appearance of the employee. }\end{array}$ \\
\hline Competence & $\begin{array}{l}\text { It refers to employee experience in handling } \\
\text { customer problem, fast response claim } \\
\text { confirmation and easy to gain information. } \\
\text { For the example is the competency of service } \\
\text { provider to handle service quickly, accurate, } \\
\text { simply and efficiently }\end{array}$ \\
\hline Corporate Image & $\begin{array}{l}\text { It refers to innovation of creating new } \\
\text { product, introducing great product, great } \\
\text { agent to serve customer properly and } \\
\text { financially stable company. These entire } \\
\text { indicators are creating a good brand image of } \\
\text { the company in front of society. }\end{array}$ \\
\hline Technology & $\begin{array}{l}\text { It refers to online customer service, easy } \\
\text { online payment and proactive information } \\
\text { through telemarketing, e-mail, SMS, online. } \\
\text { These indicators are useful in this modern era } \\
\text { in providing service more fast and efficient. }\end{array}$ \\
\hline $\begin{array}{l}\text { Personalized } \\
\text { Financial } \\
\text { Planning }\end{array}$ & $\begin{array}{l}\text { It refers to providing flexible solutions, } \\
\text { convertibility options and providing } \\
\text { personalized service. Life insurance commit } \\
\text { to long term agreement, in this case customer } \\
\text { going through to various life cycle stages in } \\
\text { this long time and his alternatives and needs } \\
\text { change according to his situation. }\end{array}$ \\
\hline Assurance & $\begin{array}{l}\text { It refers to well trained and professional agent } \\
\text { as well as their skill to convey trust, } \\
\text { confidence and how to delivered information } \\
\text { perfectly to customers. Comparable from } \\
\text { customer way of thinking are clearness in } \\
\text { explaining insurance terms and condition, } \\
\text { trusting agent when explaining the insurance } \\
\text { policy. }\end{array}$ \\
\hline
\end{tabular}

Source: Mehta and Lobo (2002)

\section{II.II. Perceived Value}

In many of determinant of either customer satisfaction or loyalty concepts, perceived value has been attracting many of researchers' concern to examine further and deeper. According to Sweeney et al (2010), perceived value is actually 'customers' overall judgment or assessment on the utility or benefit of a product using their existing perception regarding what they have received compared to what they have sacrificed". We can mathematically argue that perceived value is the total perceived benefits minus total perceived costs. Theoretically, 
customers are going to repeatedly purchase a product if there expectation have been fulfilled (Keong, Xiang, Yee, Hsien, and Pei, 2014). Subsequently, Young (2004) in the paper of Investigation of the Relationship between Perceived Value and Customer Satisfaction by Hemayatkar and Mohammadi (2015) argued that "perceived value is defined as an assessment of customer from the cost to obtain a specific good or service and the benefits that receives from a particular product or service".

The analysis of perceived value employs preferable dimensions as stated by Keong, Xiang, Yee, Hsien, and Pei (2014). They argued that important attributes of perceived value are benefit, coverage, and awareness. In practical, benefit means a situation in which a product or service can either meet or exceed customer expectation. Coverage is actually the range of how far the product or service can meet the expected needs of the customers, while awareness means whether or not the customers really perceive the benefits offered by the products or services as promised in the advertisement.

\section{II.III. Customer Satisfaction}

Since the first time people recognized what business is, there are no organizations that can be successful without providing best quality of products and services to satisfy their customers as expressed by Naebzadeh and Fatahi (2009) in the paper of the Impact of Service Quality on Customer Satisfaction:A Study on Customers of Commercial Bank of Ceylon PLC Trincomalee District by Navaratnaseelan and Elangkuraman (2014). In recent periods, there have been many researchers trying to provide best definitions and indicators of customer satisfaction. In both traditional and online business, customer satisfaction is a very crucial topic (Kadir, Rahmani, and Masinaei, 2011). Furthermore Yadaf and Dahade (2013) argued that customer satisfaction is a "personal feeling or either pleasure or disappointment resulting from the assessment of services provided by an organization to an individual in relation to expectations". Khan and Afsheen (2012) expressed that qualities of brand characteristics that are offered by a company determine the level of customer satisfaction. In addition, Malik and Ghaffor (2012) stated that "customer satisfaction is in terms of meeting the customer expectations with satisfaction".

"Customer satisfaction will lead to customer loyalty in the form of repeating purchases" as stated by Oliver (1998) in the paper of the Impact of Service Quality, Customer Satisfaction and Loyalty Programs on Customer's Loyalty, An Evidence from Telecommunication Sector by Sabir, Irfan, Sarwar, and Akhtar (2013). Furthermore Kotler and Amstrong (1999) in the paper of Service Quality Perspectives and Customer Satisfaction in Commercial Banks Working in Jordan by Mohammad and Alhamadani (2011) argued that "customer satisfaction is the customer's perception that compares their pre-purchase expectations with post-purchase perception". Meanwhile Oliver 1997 in the paper of the Factors of Influence Customer Satisfaction and Loyalty, a Study of Tea Beverage in Bangkok by Pattarakitham (2014) stated that "customer satisfaction is enjoyable level when customers buy a product or a service to meet their needs". Extensive exploration and research has been directed on these two ideas and there is understanding what give contributes to customer satisfaction could be the essential factor to gain competitive 
advantage (Siddiqui \& Sharma, 2010).

\section{II.IV. Customer Loyalty}

In order to maintain the business performance, a company has to do their best in keeping the stable sales growth. The efficient way to do it is to make sure that the customers are loyal since the cost of attracting new customers takes averagely five times higher than keeping the existing customers as stated by Kotler (1999) in the paper of the Impact of Service Quality on Customer Loyalty, a Study of Banks in Penang, Malaysia by Kheng, Muhammad, Ramayah, and Mosahab (2010). The finding is confirmed by Reicheld and Sasser (1990) in the paper of The Impact of Service Quality on Customer Loyalty, a Study of Bank Mali in Seakale City, Guilin, Iran who stated that $5 \%$ reduction in the number of existing customers results in $85 \%$ losses in the earnings of insurance companies, while $5 \%$ increase in customer retention will lead to $25 \%$ up to $125 \%$. Thus, "the term of customer loyalty is actually intended to represent the customer behavior of repeat purchase as well as those offering good ratings, reviews, and testimonials" as stated by Kumar and Advani (2009) in the paper of the Impact of Service Quality on Customer Loyalty in the Hotel Industry: An Empirical Study from Ghana by, Poku, Zakari, and Soali (2013). They emphasized that "the loyalty can only be achieved by offering the quality product through offering a firm guarantee or free offers, coupons, low interest rates on financing, high value trade-ins, extended warranties, discounts, and other incentive programs or rewards".

In the paper of Perceived Service Quality and Customer Loyalty in Retail Banking in Kenya by Auka, Bosire, and Matern (2013), customer loyalty is defined as "commitment to rebuy or repatronize a preferred product or service consistently in the future, thereby causing repetitive purchasing of the same brand, despite situational influences and marketing efforts". The paper quoted De Ruyter et al. (1998) who argued that best indicators of customer loyalty are the increase in purchase frequency (repeat purchase) and word of mouth (WOM). In practical evidence, Gitomer (1988) in the paper of Service Quality and its Effect on Customer Satisfaction in Retailing by Naik, Gantasala, and Prabhakar (2010) argued that one half of American business is built upon the informal word-of-moth communication which each of customers will tell nine to ten people averagely.

\section{II.V. Previous Studies}

The research refers to several researches with the relevant topic as exhibited in the following table.

Table 2.2 Previous Studies on Customer Loyalty

\begin{tabular}{|c|c|}
\hline Paper & Findings \\
\hline $\begin{array}{l}\text { The impact of corporate } \\
\text { image and reputation on } \\
\text { service quality, } \\
\text { customer satisfaction } \\
\text { and customer loyalty: } \\
\text { testing the mediating } \\
\text { role. Case analysis in an } \\
\text { international service } \\
\text { company. (Salam, } \\
\text { Shawky, and El-Nahas, } \\
\text { 2013) }\end{array}$ & $\begin{array}{l}\text { - There was positive and significant } \\
\text { relationship between corporate image and } \\
\text { reputation with overall service quality } \\
\text { - There was positive and significant } \\
\text { relationship between corporate image and } \\
\text { reputation with customer loyalty } \\
\text { - There was positive and significant } \\
\text { relationship between overall service quality } \\
\text { and customer satisfaction. } \\
\text { - There was positive and significant } \\
\text { relationship between customer satisfaction } \\
\text { and customer loyalty. }\end{array}$ \\
\hline $\begin{array}{l}\text { The Impact of Service } \\
\text { Quality on Customer } \\
\text { Loyalty: A Study of } \\
\text { Banks in Penang, } \\
\text { Malaysia (Kheng, } \\
\text { Muhammad, Ramayah, } \\
\text { and Mosahab, 2010) }\end{array}$ & $\begin{array}{l}\text { - Tangibles performed no significant impact } \\
\text { on customer loyalty } \\
\text { - Reliability performed positive but not } \\
\text { significant impact on customer loyalty } \\
\text { - Responsiveness performed no significant } \\
\text { impact on customer loyalty } \\
\text { - Empathy performed positive and significant } \\
\text { relationship with customer loyalty } \\
\text { - Assurance performed significant } \\
\text { relationship with customer loyalty } \\
\text { - Customer satisfaction significantly } \\
\text { mediated all service quality dimensions } \\
\text { (tangible, reliability, responsiveness, } \\
\text { empathy, and assurance) to customer } \\
\text { loyalty }\end{array}$ \\
\hline $\begin{array}{l}\text { Impact of service } \\
\text { quality, trust and } \\
\text { perceived value on } \\
\text { customer loyalty in } \\
\text { Malaysia services } \\
\text { industries (Rasheed and } \\
\text { Abadi, 2014) }\end{array}$ & $\begin{array}{l}\text { - Service Quality performed positive and } \\
\text { significant impact on Trust } \\
\text { - Service Quality performed significant and } \\
\text { positive relationship with Perceived Value } \\
\text { - Trust performed significant and positive } \\
\text { relationship with Customer Loyalty } \\
\text { - Perceived Value performed positive and } \\
\text { significant relationship with Customer } \\
\text { Loyalty }\end{array}$ \\
\hline
\end{tabular}




\section{II.VI. Research Hypotheses}

Hypothesis \#1: Service Quality has a significant influence on Customer Satisfaction.

Hypothesis \#2: Perceived Value has a significant influence on Customer Satisfaction.

Hypothesis \#3: Customer Satisfaction has a significant influence on customer Loyalty.

In detail, those hypotheses are explained by the following empirical model.

Figure 2.1 Research Model

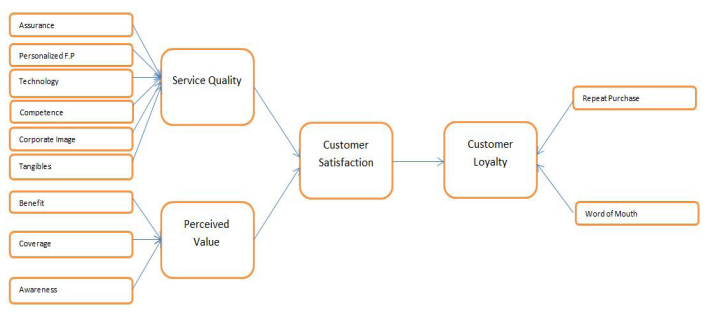

\section{METHODOLOGY}

The population of the research is obtained from PT. Synergy Adhi Manunggal customers who domicile in Jakarta, Bogor, Depok, Tangerang, and Bekasi. Moreover, the customers are chosen based on the status in which they have actively been the customer for at least one year. Sampling means a certain level or characteristics of group of population chosen to represent the behavior observed in the analysis. Sampling method is detailed into probability method selected using random sampling in which any individuals in the population has the potential to be selected as well as avoiding the sampling error and also non-probability method in which there are certain characteristics that have to be the most consideration to determine the sample in a population (Malhotra, 2010).

As the population is unlimited / unknown, the minimum number of sample is 97 samples using the above calculation; however in this research the number of samples will be used are 100 samples assuring adequate sample for the questionnaire. The larger the number of samples will produce greater sufficiency. The research employs the likert scale of 1 (strongly disagree) to 5 (strongly agree). The likert scale enables respondents to express their disagreement or agreement level on statement related to a certain object. The strength of likert scale is easy to construct, easy to distribute and easy to understand. The weakness is that the likert scale requires longer period to run. The paper uses the likert scale of $1=$ strongly disagree until $5=$ strongly agree.

\section{RESULT \\ IV.I. Validity Test}

The questionnaire are distributed to 30 respondents with total 26 questions that are designed using Likert-scale during pre-test. Table 4.1 below shows case processing summary.

Table 4.1: Case Processing Summary.

Table 4.1: Case Processing Summary. Case Processing Summary

\begin{tabular}{|cc|c|c|}
\hline & & $\mathrm{N}$ & $\%$ \\
\hline \multirow{3}{*}{ Cases } & Valid & 30 & 100,0 \\
& Excluded $^{\mathrm{a}}$ & 0 &, 0 \\
& Total & 30 & 100,0 \\
\hline
\end{tabular}

a. Listwise deletion based on all variables in the procedure.

Based on the Pearson Correlation Coefficient validity test, the variables of (1)Service Qualitywith six indicators, (2) Perceived Value with three indicators, (3) 
Customer Satisfactaction two indicators, and (4) Customer Loyalty with two indicators are valid because the correlation coefficient ismore than 0.361 (for $\mathrm{n}=30$ ) (Pearson Correlation Coefficient Table, Appendix 1 and Appendix 5).

After collected pre-test, post-test was conducted to 100 respondents.

\section{IV.II. Reliability Test}

Table 4.2 below shows that the result of reliability test. All factors of Service Quality variableare reliable because the result is greater than 0.70 .

Table 4.2: Reliability Test Result of Pre-test: Service Quality

\begin{tabular}{|c|c|c|c|}
\hline Variables & Cronbach's alpha & $\mathrm{N}$ of Items & Outcome \\
\hline Assurance & 0.893 & 2 & Very Good \\
\hline Per.Financial Planning & 0.896 & 2 & Very Good \\
\hline Technology & 0.922 & 2 & Excellent \\
\hline Competence & 0.888 & 2 & Very Good \\
\hline Corporate Image & 0.715 & 2 & Good \\
\hline Tangibles & 0.876 & 2 & Very Good \\
\hline
\end{tabular}

Therefore, all the questions of Service Quality variable are included in the second stage questionnaires distribution. Table 4.3 below shows that the result of reliability test. All factors of Perceived Valuevariable are reliable because the result is greater than 0.70 .

Table 4.3: Reliability Test Result of Pre-test: Perceived Value

\begin{tabular}{|c|c|c|c|}
\hline Variables & Cronbach's alpha & N of Items & Outcome \\
\hline Benefit & 0.748 & 2 & Good \\
\hline Coverage & 0.868 & 2 & Very Good \\
\hline Awareness & 0.887 & 2 & Very Good \\
\hline
\end{tabular}

Source: SPSS Output

Therefore, all the questions of Perceived Value variable are included in the second stage questionnaires distribution. Table 4.4 below shows that the result of reliability test. All factors of Customer Satisfaction variable are reliable because the result is greater than 0.70 .
Table 4.4: Reliability Test Result of Pre-testCustomer Satisfaction

\begin{tabular}{|c|c|c|c|}
\hline Variables & Cronbach's alpha & N of Items & Outcome \\
\hline Expectation & 0.957 & 2 & Excellent \\
\hline Service Product & 0.734 & 2 & Good \\
\hline
\end{tabular}

Source: SPSS Output

Hence, all the questions of Customer Satisfactionvariable are included in the second stage questionnaires distribution. Table 4.5 below shows that the result of reliability test. All factors of Customer Loyalty variable are reliable because the result is greater than 0.70 .

Table 4.5: Reliability Test Result of Pre-test:Customer Loyalty

\begin{tabular}{|c|c|c|c|}
\hline Variables & Cronbach's alpha & N of Items & Outcome \\
\hline Repeat purchase & 0.978 & 2 & Excellent \\
\hline Word of Mouth & 0.917 & 2 & Excellent \\
\hline
\end{tabular}

Source: SPSS Output

Hence, all the questions of Customer Loyalty variable are included in the second stage questionnaires distribution. All variables used in this study provided good reliabilities (reliability coefficients $>0.70$ ), meaning all the Likert-type questions are reliable because the Cronbach's Alpha is greater than 0.70 (Sekaran and Bougie, 2009, p.325). Based on the Pearson correlation coefficient validity test result, all questions are valid because the correlation coefficient values are greater than 0.361 and the questions in the variable is declared reliable. Therefore, these questions are acceptable.

\section{IV.III. Goodness of Fit}

Hair et al. (2010) mentioned that measurement model validity depends on establishing acceptable levels of Goodness of Fit (GOF) for the measurement which indicates how well specify model reproduces the observed covariance matrices, smaller the difference between covariance matrices estimate with the 
observe covariance matrices, more fit the model. The GOF value contains several parameters to be considered by the researcher. By utilizing AMOS software ver.22.0, the overall model fit the parameter is shown in Table 4.6.

\begin{tabular}{|c|c|c|c|c|}
\hline No. & Goodness-of-Fit Index & Cut-off Value & Value & Result \\
\hline 1 & Chi Square & $\begin{array}{l}\text { Smaller value } \\
\text { from a model is } \\
\text { better }\end{array}$ & 61.474 & Good Fit \\
\hline 2 & \begin{tabular}{|lr}
$\begin{array}{l}\text { The Minimum } \\
\text { Discrepancy } \\
\text { (CMIN/DF) }\end{array}$ & $\begin{array}{r}\text { Sample } \\
\text { Function }\end{array}$ \\
\end{tabular} & $\leq 5.00$ & 1.983 & Excellent \\
\hline 3 & $\begin{array}{l}\text { The Root Mean Square Error } \\
\text { of Approximation (RMSEA) }\end{array}$ & $\leq 0.08$ & 0.024 & Excellent \\
\hline 4 & Goodness-of-Fit Index (GFI) & $\geq 0.90$ & 0.968 & Excellent \\
\hline 5 & $\begin{array}{l}\text { Adjusted Goodness-of-Fit } \\
\text { Index (AGFI) }\end{array}$ & $\geq 0.90$ & 0.895 & Good Fit \\
\hline 6 & NFI (Normed Fit Index) & $\geq 0.90$ & 0.941 & Good Fit \\
\hline 7 & Comparative Fit Index (CFI) & $\geq 0.90$ & 0.907 & Good Fit \\
\hline
\end{tabular}

The fit indices shown in Table 4.6 have reached the requirement of standardization. All model fitness contribute a good result, the model of the plot with the information observed is matched. According to Table 4.7, all of the criteria that determine the overall fit of the model CMIN/DF (1.983), GFI (0.968), AGFI (0.895),CFI (0.907), and RMSEA (.024), were acceptable, which indicated that model fit was good. Therefore, the assumption of causal model which has been explained before already provides a statistical support.

\section{IV.IV. Hypothesis Analysis Result}

This section is aimed at interpreting results and testing of the hypothesis formulated in the study:

\begin{tabular}{|c|c|c|c|c|c|c|}
\hline $\begin{array}{l}\mathrm{N} \\
\mathrm{o}\end{array}$ & Factors & $\begin{array}{l}\text { Standardize } \\
\text { d } \\
\text { Regression } \\
\text { Weights (r) }\end{array}$ & $\begin{array}{l}\text { Square } \\
\text { Correlatio } \\
\mathrm{n} \mathrm{R}^{2}\end{array}$ & $\begin{array}{l}\mathrm{p}- \\
\text { value }\end{array}$ & $\begin{array}{l}\text { Strength of } \\
\text { Associatio } \\
\mathrm{n}\end{array}$ & Result \\
\hline 1 & Service quality & 0.72 & $52 \%$ & 0.000 & Strong & $\begin{array}{l}\mathrm{H} 1 \# 1 \text { is } \\
\text { accepted }\end{array}$ \\
\hline 2 & $\begin{array}{l}\text { Perceived } \\
\text { value }\end{array}$ & 0.65 & $42 \%$ & 0.000 & Strong & $\begin{array}{l}\mathrm{H} 1 \mathrm{H2} \text { is } \\
\text { accepted }\end{array}$ \\
\hline
\end{tabular}

The percentage show that Service Quality factor is the strongest influence customer satisfaction with standardized regression weight of $0.72(\mathrm{p}=0.000$ $<0.05$, sig.) or $52 \%$ contribution of the changes in customer satisfaction, and shows a "strong" association. Second most influence is Perceived Value factor with standardized regression weight of $0.65(\mathrm{R} 2=42 \%, \mathrm{p}=0.000<0.05$, sig.). Regarding to the maximum correlation of 1.0, these standardized regression coefficients are highly positive. Hence we can assume that a high score on the service quality and perceived value will tend to be paired with a high customer satisfaction. Therefore, the hypothesis $\mathrm{HO \# 1}$ is rejected and the hypothesis H1\#1 which states that "Service quality has a significant influence on customer satisfaction" is accepted. This hypothesis supports and proves that the service quality plays a significant influence on the overall customer satisfaction. This fundamental concept reiterates that the insurance industry should focus on the service quality to increase the customer satisfaction. This positive results support the theories and the related studies indicate similar results from Deng et al. (2010), Lai et al. (2009). Bastos and Gallego (2008) provide evidence that customer service quality directly affects satisfaction. Hence, customers with high perceived service quality also have strong satisfaction.

The hypothesis $\mathrm{H} 0 \# 2$ is rejected and the hypothesis $\mathrm{H} 1 \# 2$ which states that "Perceived value has a significant influence on customer satisfaction" is accepted. This finding is consistent with Madelano et al. (2007) result that perceivedvalue directly relates to customer satisfaction. Aali et al. (2012) says perceivedvalue has a positive influence on customer satisfaction. These findings show that service quality and perceived value are solutions to increase customer satisfaction. They can be used 
as predictors of consumer satisfaction. Like other company, insurance company has the opportunity to create loyal and satisfied customers by offering a high service quality. According to the data output, it is shown that all of the standardized regression weights are high; over 0.50 , accept Technology. It indicates that the highest contributing factor to service quality is Assurance, with a standardized regression weight of 0.86 or $74 \%$ contribution of the changes in service quality, and shows a "very strong" association.

Table 4.8: Standardized regression coefficient of customer satisfaction on the customer loyalty

\begin{tabular}{|l|l|l|l|l|l|l|}
\hline $\begin{array}{l}\text { N } \\
\mathbf{0}\end{array}$ & Factors & $\begin{array}{l}\text { Standardized } \\
\text { Regression } \\
\text { Weights (r) }\end{array}$ & $\begin{array}{l}\text { Square } \\
\text { Correlatio } \\
\mathbf{n ~ R ~ R}^{2}\end{array}$ & $\begin{array}{l}\mathbf{p} \text { - } \\
\text { value }\end{array}$ & $\begin{array}{l}\text { Strength of } \\
\text { Association }\end{array}$ & Result \\
\hline 1 & $\begin{array}{l}\text { customer } \\
\text { satisfaction }\end{array}$ & 0.78 & $61 \%$ & $\begin{array}{l}0.00 \\
0\end{array}$ & Strong & $\begin{array}{l}\mathrm{Hl} \# 4 \quad \text { is } \\
\text { accepted }\end{array}$ \\
\hline
\end{tabular}

The result of AMOS software in Table 4.8 demonstrates the standardized regression coefficient of customer satisfaction toward customer loyalty; the p-value (Sig.) of customer satisfaction in the Table 4.23 is 0.000 , less than 0.05 significant levels. It can be defined that customer satisfaction has $61 \%$ significant relationship with customer loyalty and strength association "strong". Hence, probability value ( $\mathrm{p}-$ value $<0.05$ then $\mathrm{H} 1 \# 4$ is accepted. The level of customer satisfaction is important in determining the customer loyalty. According to Kim and Lee (2011), customer satisfaction has been found to be a significant factor to determine the customers' loyalty. When customers are satisfied with a product or service, they would go back to purchase more and this creates repeat purchase.

Table 4.9: Standardized regression coefficient of word of mouth and repeat
\begin{tabular}{|l|l|l|l|l|l|} 
purchase on the customer loyalty \\
\hline No & Factors & $\begin{array}{l}\text { Standardized } \\
\text { Regression } \\
\text { Weights (r) }\end{array}$ & $\begin{array}{l}\text { Square } \\
\text { Correlation } \\
\mathrm{R}^{2}\end{array}$ & $\begin{array}{l}\text { p- } \\
\text { value }\end{array}$ & $\begin{array}{l}\text { Strength of } \\
\text { Association }\end{array}$ \\
\hline 1 & Repeat purchase & 0.77 & $59 \%$ & 0.000 & Strong \\
\hline 2 & Word of mouth & 0.68 & $46 \%$ & 0.000 & Strong \\
\hline
\end{tabular}
Source: Amos Output

The standardized regression coefficient between customer loyalty with repeat purchase and recommendation (WoM) shows positive relation. The standardized regression coefficient of customer loyalty toward repurchase intention is 0.77 (the p-value $=0.000$, less than 0.05 , sig.) or customer loyalty has 59\% significant relationship with repurchase intention and strength association "strong". The second contributor is word-of-mouth with standardized regression coefficient of 0.68 and account for 46 percent loyalty. This shows that loyal customers will lead to repeat order and also, will recommend the experiences to other people. Moreover, the results are encouraging for insurance company as very much satisfied customers would like to recommend this company to others.

\section{CONCLUSION}

The empirical finding indicates that PT. Synergy Adhi Manunggal has been successful to deliver best service quality to customers. The statistical output shows that service quality offered by the firm has been successful in satisfying the customer. It indicates that service quality becomes one of the major factors of customer satisfaction. It eventually explains that customers believe that they enjoy high quality service offered by the firm. Moreover, the result shows that perceived value offered by the company has been successful as well to satisfy the customer. It indicates that the products are able to provide high benefit (value added) to customers and to meet the customer's ultimate need regarding the insurance policies. It indicates existing emotional bond between the firm and the customers during the interaction. The next determinant is customer satisfaction that has score of 0.78 or $61 \%$ significance of 
relationship with customer loyalty. The data shows that the coefficient of standardized regression of customer loyalty on repeat purchase is 0.77 or $59 \%$ significant and strong relationship with customer loyalty. The second indicator is word-of-mouth with coefficient of standardized regression of 0.68 and represents $46 \%$ loyalty. Even though repeat purchase shows performs significance on customer loyalty of PT. Synergy Adhi Manuggal that both possess positive relationship.

There are six dimensions of service quality determining customer satisfaction and loyalty employed by the research. Service quality dimensions of assurance, personalized financial planning, technology, competence, corporate image, and tangibles should be effectively maintained to improve customer satisfaction and loyalty of PT. Synergy Adhi Manunggal, especially technology dimension that plays least significant role in forming customer satisfactions. It indicates a necessity to enhance the quality of technology by improving the system that connects between internal of firm as well as between the firm and the customers. Technology is actually related to service aspects such as providing more responsive customer services towards any questions, claims, and complaints, continuous updates (email-based subscribe), and periodic notifications in terms of, for instance, premium payment and investment dynamics. In terms of coverage, agents of the firm have to be more clear and proactive in providing information based on customer's current need so that they can choose the products that fully cover their actual demand.

\section{REFERENCE}

Anber Abraheem Shlash Mohammad \& Shireen Yaseen Mohammad Alhamadani (2011)/ "Service Quality Perspectives and Customer Satisfaction in Commercial Banks Working in Jordan" / Middle Eastern Finance and Economics ISSN: 1450-2889 Issue 14 (2011) C EuroJournals Publishing, Inc. 2011

Anderson, J.C. and Gerbing D.W. (1988): Structural Equation Modeling in Practice: A Review and Recommended Two - Step Approach. Psychological Bulletin, 103, 411-423.

Angelova, B., \& Zekiri, J. (2011). Measuring Customer Satisfaction with Service Quality Using. Hrmars.

Auka, Bosire, and Matern (2013), "Perceived Service Quality and Customer Loyalty in Retail Banking in Kenya ".Vol1 - Issue-3 September-2013. Europian American Journal.

Burns, A. C. \& Bush, R. F., 2006. Marketing Research. 5th ed. New Jersey, USA: Pearson Education,Inc.

Choi cheng keong, chua chiau xiang, katrin koh sze yee, lai mei hsien, tan wen pei (2014)/ "Determinants of customer satisfaction in conventional insurance services: the case of malaysia", n.d

Cooper, D. S., \& Schindler, P. S. 2006. Business Research Methods (10th Edition ed.). New York: Mc Graw Hill International Edition.

Daniel Onwonga Auka, Joseph N. Bosire,Victor Matern (2013). Perceived Service Quality and Customer Loyalty in Retail Banking in Kenya/ British Journal of Marketing Studies Vol.1, No.3, pp. 32-61, September 2013 Published by European Centre for Research Training 
and Development UK

Deng et al. (2010, p.291 Understanding Customer Satisfaction and Loyalty: An Empirical Study Of Mobile Instant Messages In China, International journal of Information Management Vol.30, 2010 entitled,

De Ruyter, K. Wetzels, M., and Bloemer, J. (1998) "On the Relationship between Perceived Service Quality, Service Loyalty and Switching Costs," International Journal of Service Industry Management, Vol.9, pp. 436-53.

Eman Mohamed Abd-El-Salam, Ayman Yehia Shawky and Tawfik El-Nahas (2013). "The impact of corporate image and reputation on service quality, customer satisfaction and customer loyalty: testing the mediating role. Case analysis in an international service company". The Business \& Management Review, Vol.3 Number-2

Rasheed F.A. and Abadi M.F. (2014). Impact of Service Quality, Trust and Perceived Value on Customer Loyalty in Malaysia Services Industries.International Conference on Accounting Studies. Volume 164.

Gitomer, J. (1998). Customer satisfaction is worthless, customer loyalty is priceless: How to make customers love you, keep them coming back, and tell everyone they know. Austin, TX: Bard Press.

Haitham Hmoud Alshibly (2015) "customer perceived value in social commerce: an exploration of its antecedents and consequences".journal of management research.vol 7, no 1 .

Hair, J.F.Jr., Black, W.C., Babin, B.J., Anderson, R.E., \& Tatham, R.L. 2006. Multivariate Data Analysis. 6th ed. New Jersey: Pearson Education Inc.
Hair, J.F.Jr., Black, W.C., Babin, B.J., Anderson, R.E., \& Tatham, R.L. 2010. Multivariate Data Analysis. 7th ed. New Jersey: Pearson Education Inc.

Hazlina Abdul Kadir, Nasim Rahmani, and Reza Masinaei (2011).“Impacts of service quality on customer satisfaction: Study of Online banking and ATM services in Malaysia".international Journal of Trade, Economics and Finance vol.2, no.1.

Kheng, L. L., Mahamad, O., Ramayah, T., \& R. M. (2010). the impact of service quality on customer loyalty: a study of banks in penang Malaysia. international journal of marketing studies, 58.

Kim, Y. K. \& Lee, H. R., 2011. Customer satisfaction using low cost carriers. Tourism Management, Volume 32, pp. 235-243.

Kofi Poku, Mariama Zakari, Ajara Soali (2013). "Impact Of Service Quality On Customer Loyalty In The Hotel Industry: An Empirical Study From Ghana" / International Review Of Management And Business Research / Vol 2 Issue 2

Krishna Naik C.N, Swapna Bhargavi Gantasala \& Gantasala V. Prabhakar (2010)/ "service quality (servqual) and its effect on customer satisfaction in retailing".European journal of social sciences.volume 16, number 2 .

Kumar, R. S. and Advani J.Y. (2009). Factors Affecting Branding Loyalty: A study in an Emerging Market on Fast Moving Consumer Goods. Indian Institute of Management Bangalore.

Lai, F., Griffin, M., \& Babin, B. J. (2009). How quality, value, image, and satisfaction create loyalty at a Chinese telecom. Journal of Business Research, 62(10), 980-986.

Levine, L., Stephan, D., Krehbiel, T. 
\& Berenson, M., 2008. Statistics for Manager. 5th Edition ed.: Pearson Prentice Hall.

Lo Liang Kheng, Osman Mahamad, T Ramayah, Rahim Mosahab (2010).“the impact of service quality on customer loyalty, a study of banks in Penang, Malaysia".International Journal of Marketing Studies.volume 2 issue 2.

Mehta, \& Lobo. (2002). MSS, MSA and zone of tolerance as measures of service quality: a study of the life insurance industry. second international services marketing conference. queensland.

Malhotra, N. K., 2010. Marketing Research, An Applied Orientation. 5th ed. s.1.:Upper Saddle River, NJ, Prentice Hall Inc.

Maryam Talebi ,MA Dadashi , K Ezzatdoust, K Farajy (2012)."The Impact of Service Quality on Customer Loyalty: A Study of Bank Mali in Seakale City, Guilin, Iran".International Research Journal of Applied and Basic Sciences./ Vol, 3 (10): 2120-2126 Science Explorer Publications.

Masood H Siddiquil and Tripti Ghosh Sharma (2010).“Analyzing customer satisfaction with service quality in life insurance services".journal of Targeting, Measurement and Analysis for Marketing (2010) vol 18.

Mehta, S.C., Lobo, A., \& Khong, H.S. (2002). MSS, MSA and zone of tolerance as measures of service quality: a study in the life insurance industry. Second International Services Marketing Conference, University of Queensland.

Money Control. (t.thn.). Unit Linked insurance Plan. Dipetik march 11, 2015, dari Financial Portal: http://www. moneycontrol.com/insurance/ulip/iciciprudential-life-insurance-IP.html
Naik C.N.K, Gantasala S.B., and Prabhakar G.V. (2010). "Service Quality (Servqual) and its Effect on Customer Satisfaction in Retailing". European Journal of Social Sciences - Volume 16, Number 2 (2010).

Nasrin Hemayatkar \& Zeinab Mohammadi (2015)/ "Investigation of the Relationship between Perceived Value and Customer Satisfaction".International Research Journal of Management Sciences /Vol., 3 (3).

Navaratnaseelan J.J And P. Elangkumaran (2014). "Impact Of Service Quality On Customer Satisfaction: A Study On CustomersOfCommercialBank OfCeylon PLC Trincomalee District".Reshaping Management And Economic Thinking Through Integrating Eco-Friendly And Ethical Practices Proceedings Of The 3rd International Conference On Management And Economics.Faculty Of Management And Finance, University Of Ruhuna, Sri Lanka. Nv.

Nelson, R. (2012, February 2). The Importance of Customer Satisfaction. Dipetik March 24, 2015, dari wparesearch. com: http:/www.wparesearch.com/ uncategorized/the-importance-ofcustomer-satisfaction/

Neetu Bala, Dr. H.S Sandhu, Dr. Naresh Nagpal (2011 october)."Measuring Life Insurance Service Quality: An Empirical Assessment of SERVQUAL Instrument". journal of International Business Research/ Vol. 4, No. 4.

Paul, M., Thurau, T. H., Gremler, D. D., Gwinner, K. .., \& Wiertz, C. (2008). Toward a theory of repeat purchase drivers. Academy of Marketing Science.

Patrick, R. R., (1997). Teams and conflict management style: The moderating effect of conflict management style on the 
relationship between the type of conflict and team effectiveness in continuous work teams, Lincoln: Unpublished doctoral dissertation, University of Nebraska.

PRU Smart Synergy. (2009 - 2013). Production of PRU Smart Synergy. Jakarta.

Prudential, I. (2013). History. Dipetik march 11, 2015, dari Prudential Indonesia: http://www.prudential.co.id/ corp/prudential_en_id/header/aboutus/ ourhistory/index.html

Poku, Zakari, and Soali (2013). "Impact of Service Quality on Customer Loyalty in the Hotel Industry: An Empirical Study from Ghana". Vol. 2 Issue. 2 , (June, 2013), ISSN: 2306-9007 International Review of Management and Business Research.

JainP.\&KumarA.K.(2015)."Investigating The Moderating Role Of Switching Cost In The Relationship Of E-Service Quality, Perceived Customer Value, Satisfaction And Loyalty Towards Online Travel Agencies".Vol.03 Issue-03, (March, 2015) ISSN: 2321-1784 International Journal in Management and Social Science.

Raquel Sánchez-Fernández and $M$. Ángeles Iniesta-Bonillo (2007). "The concept of perceived value: a systematic review of the research". Marketing Theory. Volume 7(4).

Raja Irfan Sabir, Muhammad Irfan, Muhammad Arslan Sarwar, Binesh Sarwar, Naeem Akhtar (2013).“The Impact of Service Quality, Customer Satisfaction and Loyalty Programs on Customer's Loyalty: An Evidence from Telecommunication Sector".Journal of Asian Business Strategy 3 (11).

Raja Irfan Sabir, Muhammad Irfan, Muhammad Arslan Sarwar, Binesh Sarwar \& Naeem Akhtar (2013)."the impact of service quality, customer satisfaction and loyalty programs on customer's loyalty: an evidence from telecommunication sector".journal of Asian business strategy. vol 3, issue 11 .

Rasoul Asgarpour, Abu Bakar A. Hamid , Zuraidah Binti Sulaiman (2015).“A Review on Customer Perceived Value and Its Main Components".Global Journal of Business and Social Science Review. GJBSSR, Vol. 1 (2), January-March 2015: 632-640.

Rajesh. K. Yadav \& Mr Nishant Dabhade (2013)/ "impact of service quality on customer satisfaction of mobile users - a case study of Airtel".international journal of innovative research and studies.vol 2, issue 5 .

Riley, J. (2009, May 1). Business Blog. Dipetik March 12, 2015, dari beta.tutor2u. net: http://beta.tutor2u.net/business/blog/ qa-what-is-repeat-business-and-why-isit-important

Salam E.M., Shawky A.Y. and Nahas T.E. (2013), "The impact of corporate image and reputation on service quality, customer satisfaction and customer loyalty: testing the mediating role. Case analysis in an international service company", The Business \& Management Review, Vol.3, Number-2, pp. 177-196

Sekaran, U. \& Bougie, R., 2013. Research Methodology for Business - A Skill Building Approach. 6th ed. West Sussex: John Wiley \& Sons Ltd.

Setiawan, E. (2015, April 6). (B. W. Andhika, Pewawancara)

Setiawan, E. (2015, march 9). Company Background. (B. W. Andhika, Pewawancara)

Siddiqui, M. H., \& Sharma, T. G. (2010). Analyzing customer satisfaction with service quality in life insurance services. 
Journal of Targeting, Measurement and Analysis for Marketin.

Loke S.P., Taiwo A.A., Salim H.M. and Downe A.G. (2011)."Service Quality And Customer Satisfaction In A Telecommunication Service Provider". International Conference On Financial Management And Economics IPEDR Vol 11.

Sondoh Jr, S. L., Omar, M. W., Wahid, N. A., Ismail, I., \& Harun, A. (2007). The Effect of Brand Image on Overall Satisfaction and Loyalty Intention in The
Context of Color Cosmetic. sian Academy of Management Journal, Vol. 12, No. 1, 83-107,, 92.

Spirtes, P. Richardson, T. Meek, C. Scheines, R. Glymour, C. (1998). Using Path Diagrams as A Structural Equation Modeling Tool. Department of Philosophy, Carnegie Mellon University.

Syed H, A. (2010). Service Attributes Satisfaction and Actual Repurchase Behaviour. Journal of ConsumerSatisfaction, Didsatisfaction and Complaining Behaviour. 